\title{
CREATIVE TECHNOLOGIES IN ADVERTISING DESIGN
}

\author{
Svitlana VALERIIVNA PRYSHCHENKO* \\ National Academy of Managerial Staff of Culture and Arts, Institute of Design and Advertising, \\ Department of Graphic Design, 01015 Lavrska str. 9, bild. 15, Kyiv, Ukraine
}

Received 5 February 2019; accepted 20 April 2019

\begin{abstract}
The purpose of this article was analyses the existing methodological approaches to art, culture, design, advertising for the further effective designing of advertising products, increasing its positive value orientations and aesthetic level. The research area is the visualization of advertising ideas taking into account of regional specificity and ethno-cultural identification. Scientific study of cultural-aesthetic component in advertising design has the aim to systematize visual means of information and make a complex definition of their functional specifics in contemporary society, which is much wider than thirty years ago. The advertising graphics presented as visual art, visual culture and visual communication. On examples, we considered the creative advertising technologies: metaphors, hyperbole, associations, allegories and metonymies using colour-graphic imaginative means. Orientation of products to regional consumer groups, significant change of market policy presupposed cardinal change in tasks and character of advertising: socio-psychological, cultural and art-aesthetical indices become actual. Definition of imagery as specific tool of creativity on the point of view different aesthetic ideals is a key to understanding the process of art projecting. So, our comprehensive research summarizes stylistics of advertising graphics in the context of cross-cultural communications from posters to new advertisings forms - digital media.
\end{abstract}

Keywords: advertising design, advertising graphics, artistic imagery, poster, digital media, visual aesthetics.

\section{Introduction}

In the near future, creativity in many areas of activity, communicativity and digital literacy will be increase. In our opinion, its especially relevant for design and advertising in the context of cross-cultural interaction. One of the priority directions of research is creative advertising technologies and artistic imagery in advertising at the relations between local, regional, global and transnational cultures. The aim of article is to characterize art-aesthetic problems of advertising design (AD). The scientific novelty of our results is consists the comprehensive analysis of advertising graphics (AGs) as design component and form of socio-cultural communications, and the general prospects for the $\mathrm{AD}$ development into account computer technologies were discussed.

*Corresponding author. E-mail: akademiki@ukr.net 
Advertising (commercial) graphics occupies significant place in the area of commerce, industry and culture of different countries as one of the most important elements of products and services identification and recognition of their manufactures in current informative society. $\mathrm{AD}$, combining all the achievements of art, design and marketing, developed gradually. At the beginning of the 21st century, great changes in the views on design and advertising appeared within the processes of globalization and, at the same time, ethno-cultural identification, overuse and lowering cultural level of society. Huge social changes followed by the development of technologies caused the ideas of universal humanistic design of products "for all and everyone", where advertising plays very important role promoting products to the mass market.

Limited publications in the post-Soviet space recognize advertising, despite its main commercial function, a cultural phenomenon. But most often, modern means of advertising informing do not contribute to the formation of the worldview, the development of artistic thinking, the aesthetic perception of reality, etc. Well known American graphic artist William J. Bovman noted that visual language (VL) is not an end in itself - the form, space, and visual interaction become tools for visualizing ideas (1971).

Foreign scientists outline two tendencies in advertising: specifically, pragmatic and historically cultural. First presupposes fast training of advertising business practitioners: designers, managers, marketologists who promote products, services and companies getting profits very quickly. Second oriented on understanding the sense of cultural, psychological and aesthetic conceptions of advertising and its influence on different society sub levels, taking into account national specific peculiarities of advertising process in different countries. However, most of advertising sources do not consider advertising as a part of design, and the development of advertising informative means is given shortly, without any complex understanding of visual changes in printed and digital media. Without diminishing the value of individual research papers (Rozik, 1997; Malamed, 2009; Noble \& Bestley, 2011; Margolis \& Pauwels, 2011; O'Connell, 2015; Ehmer, 1980; Wernick, 1991), it is worth noting that beyond the attention of scientists there are such important issues as the regularities of the development of the create image in the process of disclosing advertings ideas.

\section{Methodology and theoretical framework}

The integrative character of advertising industry (AI) determines methodological approaches and scientific methods. In accordance with the selected multimodal and trans-system approaches, the author substantiates and discloses seven necessary methods: system-structural, socio-cultural, axiological, art historical, comparative, synergetic and semiotic. Consider each of them in more detail.

\section{Results of the research}

\subsection{Scientific research of the culture-aesthetic components of advertising communications}

The main point of scientific problem is in the necessity of concretization of professional terminology, increasing and deepening theoretic-methodological fundamentals of $\mathrm{AD}$ as 
independent area of art-projecting culture. The object of the research presupposes consideration of general methodology of design with classic setup methods in industrial and environmental design, but also with very specific aspects of advertising.

The scientific novelty of presented work is to develop the theoretical and methodological principles of comprehensive analysis of AGs as a product of culture and as a component of $\mathrm{AD}$, which combining the creative visual means of art, of design activity and the creative advertising technologies.

The object of our research - advertising creativity in the context of socio-cultural communications.

The subject of research - advertising graphics as art component of designing advertisements.

The English termbase contains the definition of many elements of advertising (commercial) activity, marketing and branding, however, from our view point, it does not holistic expose the essence, role and potential of visual advertising as the cultural phenomenon and instrument of intercultural dialogue at different levels of consumption: products, domestic and tourist services, advertising support for cultural-image sphere (fine art, decorative arts, architecture, theater, cinema and television, literature, music), and for the events of national cultures promoting in the world. In general, understanding the value of creativity in contemporary advertising cardinally changes its focus on target groups, as noted by Jerome Jevler: advertising strategies (advertising ideas) should be represents in bright and attractive images in certain styles of cultural-artistic diversity (2003, pp. 122-130). Neil Kokemuller very briefly deals the design principles as a set of accepted the visual recommendations that must be followed for aesthetically pleasing advertisement:

"Though terminology varies, the principles includes balance, hierarchy, proportion, emphasis and unity. Creativity is critical to effective advertising. Many brands have used creativity to build brand images with greater meaning the basic capabilities of their products" (2019).

So, the interdisciplinary research of cultural-aesthetic component of AI has the idea to systematize and classify visual means (VMs) of ad and complex identification of their functional and visual peculiarities in communicative area that is much wider than 30 years ago. Definition of "advertising communication (AC)" is coded with colour, word and sound in special information for potential audience presupposing feedback, and they become the instrument of trade and social trend. In other words, advertising can be considered as a special kind of social mass communications that fulfills three main functions: informative, commercial and social. Advertising unites the achievements of several sciences: economics, marketing, sociology, psychology, philosophy, philology, cultural studies, and, of course design and current industrial and computer technologies. The above-mentioned syncretism can be defined as "advertising art" with advertising transmitted into the art of psychological manipulations with the aim to get profits in the terms of overproduction and rising competition.

Scientific attitudes to advertising and, especially to the classification of visual information (VI), we understand as means of thinking and cognition, at the same time, methods of research as definite algorithms and systematic steps to reach the aim. Realizing complex research of AGs in the structure of design we used the following methodological compass taking into account 
advertising trans-systematic integrated character overcoming borders of definite socio-economic systems. In other hand, multimodal attitude is the best to understand the matter of ACs and allows uniting both methods and use advantages of each chosen in our research.

System-structural method gives the possibility to analyze AD as the area of activity and its individual factors on the level of their synthesis in thinking over its functional, technological, marketing and cultural aspects of visual-informative environment: urban, subjectable (packing, ad-souvenir goods), virtual, etc. System in design is a complex of necessary and useful elements, which have interrelations between each other and compose the whole. Composition of elements covers social-economic points, problems of synthesis functional and aesthetic aspects, ecological and rational use of materials. Every structural element of form in design fulfills its defined functions meeting needs of the whole system. However, design can be appreciated as a creative method, process and a result of art-projective activity for meeting utilitarian, social and aesthetic needs of the consumer. Based on the concept of Victor Papanek, we emphasize three basic requirements for design: functionality, constructivism and aesthetics (2004).

Dynamic development of industrialization and urbanization, standardization of mass production, development of media and the ascendancy of mass culture have identified specific development of art and design culture. During the above-mentioned period design as project area formed in independent type of professional activity, establishing general principles of design from the advanced industrial countries of the world (Sydorenko, 1990).

Art had powerful influence on the development of design. Evolution of practical design shows a significant role of world art culture in the formation of styles in the varieties of design. Nowadays, design can be defined as arranging of index or a virtual world, where socio-cultural area, forms and their interrelations in human life are organized particularly. Design became a complicated system, which provides the development and functioning of tangibles, organization and transformation of artificial or natural environment, i.e. art-project culture and technological (production) culture.

Formation of advertising relates to the development of trade connections and manufacturing. Collection and systematization of empirical data of AGs as an independent branch of design is very important for awareness with principles of advertising ideas visualization and accomplishing outcomes - commercial or social in order to promote social, cultural or political ideas. Current research in Harvard University Graduate School of Design is based on the assumption that majority of key problems and possibilities nowadays require the collaboration of the arts, humanities, industry and the public sphere (2019). In addition, principles of design thinking in Stanford d.school is a methodology aimed at creating products that solve real problems of people and the society (dschool.stanford.edu, 2019). Design Council considers obvious the importance of design for countries' economies. Design contributes to innovations and production growth that needs significant increase of design activities on regional level, such as access to education, to practice, design management and design marketing (Design Council, 2019). Research Park at University of Illinois at Urbana-Champaign, United States (US) chose the slogan of its design activity "New Thinking. New practices. New Society" (Research Park, University of Illinois Urbana Champaign, 2019). The most effective interdisciplinary design strategies are currently being demonstrated, as evidenced by the 
European scientific conferences and thematic seminars on design and visual communications (VCs) in Munich, Leipzig, Berlin, London, Stockholm, Le Havre, Warsaw, Krakow, Sofia, Saint Petersburg, Milan, Prague, Helsinki, Vilnius, Vienna, Basel, Neuchâtel, Zurich also.

Socio-cultural method of VMs of advertising evolution research allows defining AGs as a reflection of historical, socio-cultural, economic, technological and political stages of society development. Advertising as design always has ideological platform, communicative tasks and motivational setting up that helps to realize the evolution of advertising stylistics within the framework of certain cultural formations but led to the emergence of mass culture and extensive AI. Anna Kostina considers the main feature of modern socio-cultural area is interrelation of mass, elite and folk cultures. Mass culture escalating after World War II borrowed, replicated and extended cultural samples and adapted individuals to definite environment. Being significant system accessible to all social sub-layers, mass culture acts as a mechanism of formation actions and relevant communications (Kostina, 2011).

Polina Gerchanivska presupposes that socio-cultural systems are the result of human creativity:

" $<\ldots$. > based on the technology of mass manipulation (printed and digital media, advertising etc.) institutions provide information-psychological influence on people. Important mechanism of the socio-cultural system regulation is mass culture that leads to maximum standardization not only social norms, but also ideological and philosophical orientations of people" (2017, pp. 4-5).

The term "communication" appeared at the beginning of the 20th century as a means of information exchanged between any objects, but alongside with this scientific meaning acquired socio-cultural content and became a process of exchanging emotional and intellectual information. Manuel Castells emphasizes that communications now take the first place. Media has become a sphere where serious strategies are being played. In the current technological context, communications go beyond the traditional media, in particular the poster, and include digital media (DM) - Internet and mobile communications (Castells, 2009). The existence of common language between communication entities (individuals, groups, organizations, etc.), channels of delivering information, and specific rules of communication practice in definite cultures (semiotic, ethical, etc.) are necessary conditions and structural components of communication aiming formation of social relations, regulation of particular forms of society functioning, accumulation and transmission of cultural experience.

Socio-cultural method is based on the system-structural one with its core society review as a harmony of culture and communications, and qualitatively different cultural phenomena that appear in the process of its development. An important study of sociocultural approach to artistic activity is in Yuri Afanasiev monography, where the author says:

"Products of artistic activity - images acquire social meaning only within complex understanding of cultural processes. Defined content has it sense in the synthesis of emotional and rational components, provided in the form of sensual image represented in definite cultural and communicative contexts and associative relations" (1990, p. 30).

Specific kind of culture - art-projecting culture or design was formed during 20th century (Danylenko, 2005). We consider design at the junction of cultures: artistic (art), intellectual (science) and technical (industrial). Design can be outlined as highly specialized area of ac- 
tivity, but designers have as a rule, broad enough outlook, know materials and technologies well but the most important their quality is understanding needs and desires of consumers. It is very hard to define the object of design out of art, science and engineering for the reason that design products vary greatly from equipment to image created with advertising tools. Contradictions are found in social and economic systems since harmonious environment of human existence should be united with high level of incomes. The main purpose of the designer is to provide a specific object of design (mass or luxurious) with consumer value. All partial tasks as improvement of functional and constructive characteristics of the product, increasing its comfort of use, adapting to fashion requirements through changing form, color, new packing are combined in an entity if a complex design product (not as object of projecting) is reflected on consumer value. Within the system "manufacturing - application" objects of design become things that satisfy not only substantial requirements but also convey aesthetic values as elements of artistic-imaginative attitude to the reality and self-expression of the individual as in the process of projecting as in the process of application (usage). Thus, design is a systematic aesthetic activity aiming realization of aesthetic directions and human values, creating new forms and developing artistic taste. Objective world is very important for designer with variable products or posters that become not only a part of it but express definite semantic connotations to consumers.

Jorg Frascara understands AD as a process from idea, planning, constructing, coordination, to the selection and organization of pictorial and text elements. VC deepens the essence of design and relates it to the projecting of visual objects (VOs), aimed at the transmission of information in specific messages based on the principles of expediency, structuring, aesthetics and further evaluation of efficiency (Frascara, 2004, p. 3).

Current discourse in the area of design research, art and cultural studies, media research, philosophy and social sciences in Swiss Design Network contains main progressive message about design as a catalyst for global change. On the background of natural and manufactured disasters, climate changes, socio-economic crises society needs designers as creators of visual functioning forms. At the junction of material and spiritual cultures, new forms of activities appear in the market. One of the best examples is design with its products, which become simultaneously products of society, culture, definite epoch and a creativity result of individual artist, designer or advertiser (Swiss Design Network, 2019).

Thus, AG should be considered not only as a cultural phenomenon as a fact or creation of attractive visual but as original product, conditioned by a combination of needs, values and norms of definite historical period. However, axiological method of research will be the most relevant here. Valery Sivers offers extension of methodological arsenal of cognition from its initial sources on the base of syncretism. According to him, "cognition is the realm of metaphors and analogies" (Sivers, 2014, p. 24). He calls value (in the dimension of cultural studies, in spite of the fact that its boarders are absolutely clear) as something that keeps human way of existence with creation, maintenance and transformation conditions of denial the contemporary state of human existence. As a result, this "something" is the ratio between the conditions of human existence and the sense of human existence in these conditions. The whole set of meanings, in spite of their diversity, create sustainable value. It can be considered as relevance value or horizon of the value cultural field (Sivers, 2014, p. 25). 
Antony Giddens considers that any culture does not exist without society, and any society cannot exist without culture. Social values express general purposes, play role of fundamental norms of human behavior and communication, serve as social indicators of living quality, provide the choice of rational actions and create inner core culture, spiritual quintessence of needs and interests of individuals and social groups. System of values, in turn, has a reverse effect on social needs acting as one of the most important incentives in social interaction (Giddens, 1999, p. 43).

Referring to the Ukrainian-Polish researcher Roman Sapeńko, who examines communicative, semiotic and cultural-aesthetic aspects of advertising and claims that core competence of advertising appeal is axiological complex that helps to touch individual values and desires of consumers. This complex becomes a basis for other elements of advertising world (Sapeńko, 2005, p. 255). Additionally, we claim that modern advertising actively forms trends for a certain lifestyle, social behavior, principle of consumption and moral norms. Nowadays, ideals, values, cultural samples, heroes from different ages are mixed by following, borrowing and reproducing.

Art historical and critic method matters uncovering typological features of art styles, their periodization, significant influence on advertising creativity since different epochs and regions represent different archetypes, canons, ethno-art traditions, stylistic tendencies, fashionable trends significantly reflected in the advertising products. Image-stylistic analysis of notices and posters for several centuries allows uncovering principles of compositional organization in European, Asian, American and Ukrainian advertising areas. From art historical and critic point of view stylistics and art peculiarities of African advertising is very interesting.

Advertising assimilates and uses cultural experience, "embeds" in the history of culture. Study of art styles significantly affects understanding of historical processes and relevant patterns of AG development. In the terms of globalization, national cultures meet serious challenges and acquire contradictory displays. However, comparison provides generalized results of the analysis national and international aspects of advertising for sales stimulation and image support taking into account specifics of different channels for social, cultural and political areas.

Using creating world comparativistics, foreign scientists presuppose the appearance of hypermedia and creation of world online bank of commercial advertising images that also can be used with educational purposes. Dismissing the Internet as the only source of advertising in the future, they consider that mixed formats mixed formats will serve as a bridge for the expected but still a completely uncertain digital future (Stanczak, 2007, p. 17). The poster still retains its importance as the main advertising medium both in the city environment and in the interiors. Thus, visual researches (VRs) of advertising materials have a great potential to supplement other methods of study and understanding social world.

Lev Manovich notes that digital technology and science are increasingly shaping culture, while new media (NM) opens up a new page in the history of design and ACs. Different carriers of digital information (text, sound, static (drawings, schemes, photos)) and dynamic images (animation or video) work simultaneously in electronic media (multimedia). Vector and raster graphics allow to create visualizations of any complexity, without any problems to make changes to them. Contemporary communication channels can not be others, so 
the part of "multi-" disappears as outdated. The emergence of the term "hypermedia" - the channels equipped with a large number of identified components, means the efficiency in finding and viewing the necessary information. The author distinguishes between two basic levels in DM - technical (computer) and cultural, paying attention to their closest mutual influence. The general trend in culture under the influence of computerization, he sees the differences in the design process, since designers of NM need to considers multifactoriality of postmodern (Manovich, 2002).

Synergetic method together with system-structural becomes modern theoretical basis of innovative processes in the area of media culture, a key to increasing social significance of art, design and advertising, movement from creativity to productivity in the promotion of goods and services. Synergetic (earlier - cybernetics) is a relatively new fundamental method of cognition with the essence in study of systems of various nature: physical, biological, technical, social, cognitive, informational, environmental, etc. Synergetic statements allow us to understand the laws of the development of society, nations and their peculiarities, corresponding contradictions, and so on. This phenomenon with complex influence of involved factors gives much higher effect than the sum of each of them separately. Arthur W. Page's (US) cumulative strategy recommends increasing costs on analyzing and evaluating efforts and reducing costs on solutions that may be inappropriate (Griese, 2001). That gives the opportunity to exclude creating bad projects with the aim to learn how to create well-made projects. However, the more introduced requirements for the design of an object, the more difficult becomes the analysis and assessment, and the more difficult to coordinate them all in the process creating a particular product (Pryshchenko, 2018, pp. 27-28).

Volodymyr Fed underlines in his work that postmodernism transforms and modifies the idea of methodology as it is, i.e. of classic methodology. Synergetic method acts as a multivector according to deconstructivism favorite theme of chaos, promotes awareness of the processes of culture, and serves as a synthetic basis for other methods. Synergetics emulates the internal principle of the system method, in other words, principle of combining different methodologies. Instead, the external form of implementation this internal principle is organization, including streamlining the structure and functioning. Named method forms alternative, multiplicity of methodological ways for analysis of complex systems (Fed, 2009, pp. 21-22).

This synergistic theory, developing methodology of system research, opens new possibilities of self-developing and self-organizing patterns for modern Ukrainian society, which is undergoing the transformation in terms of the world's globalization and alternative deepening of regional identifications. Famous Bulgarian advertiser Hristo Kaftandjiev considers essential the following phenomena in modern advertising signs, the presence of semiotic core, communicative synergy, evanescence, incompleteness, polysemy, inconsistency, mockery. By advertiser, they help to understand the appeal generally but, in fact, they are destructive and lack of aesthetics (Kaftandjiev, 2012, pp. 390-391).

Semiotic method facilitates understanding of AGs as a sign system: its utilitarian, aesthetic informative and artistic imagery as an ideological product of AD. Semiotics examines signs and sign structures that represent or keep information and determine systematic processes in nature, society and communication, exploring meanings and semantic relationships. This 
science became a basis of the theory of graphic design as VC. Semiotic analysis allows us to find out how advertising appeal is organized, what it expresses and what elements always reveal certain ideological principles laid down in it.

Umberto Eco had the idea that all human spiritual activity is identified by encoding and transcoding, and it is impossible to find the latter meaning during decoding process (2019). The latest ideas of order and chaos make it possible to introduce the concept of "information" as an explanation of the notion "meaning". Synergetics submitted information properties of the world in dependence with the integrity of the system, therefore, old paradox "the whole is more than the sum of the parts" has gained real physical sense. Analysis of semantic structures of culture influences to reassess certain deterministic views, where study of cultural features of different epochs and societies can rely on a verified empirical material since mythopoetic consciousness coincides cognitive, stimulating and expressive dimensions. Cultural ecosemiotics studies the influence of culture on possible interpretations of the environment. Roland Barthes' semiological understanding of reality depended on ideology, cultural context, historical epoch, etc. (2003).

Advertising is a special form of communication that is rapidly gaining the space of DM, where directed information-oriented or expressive-suggestive messages are distributed. To achieve the effective influence, advertisers use various approaches of delivering messages to the audience with information about real or psychological benefits from buying the product under advertising. Encouraging consumers to perform the pre-programmed actions occurs through the choice of strategies and tactics, which are realized on semiotic level with the help of diverse coded tools (visual, verbal and mixed). Semiotic method also provides understanding of posters' images, which are closely intertwined with social, political, cultural and technological processes. Yuri Lotman noticed that society exists in a complex organized world of meanings and values of culture, diversity of code layers that have value-semantic interaction. Dialogue between cultures is sharing views within a single semiosphere. It is a complicated process of understanding the meaning of their own culture, bringing it to other cultures and simultaneous search of ethnic differences, specific mentalities and others (Lotman, 2001, p. 547).

Polish sociologist Petr Shtompka is considered to be the author of "VR" (2007). In his opinion, the above mentioned is the analysis of social views that are transmitted from one social group to another with the help of images, which he offers to consider as a complete act of communication with all its elements included. Visual methodologies study socio-cultural phenomena through the prism of visual images and representations in the form of photos, films, and advertising. The main reason for the emergence of this new interdisciplinary industry is the growth of the social significance of VI in comparison with verbal and substantial objects. Nowadays it is more important for manufacturing and commerce to produce not consumer goods but images that are easy to remember, imitate and borrow. Visual streams get victory over verbal; new fragmentary, "clip" bound, based on emotional platform and built precisely on visibility, variation and perception of a large number of various elements thinking is coming to human life.

Malcolm Barnard in the section "Semiology, Iconology and Iconography" (2001, pp. 143159) indicates that Charles Sanders Peirce in his essay "The Theory of Signs" (1934) observed semiotics as a science and considered it a "formal doctrine of signs", distinguishing three types 
of characters: icon, index and symbol. Later semiotics acquired the status of an instrument for visual analysis of the environment. In the early 1970's, scientists established the idea about aesthetics of modernism based on geometric forms that exhausted itself since the absence of ornaments as signs and symbols inhibited the main means of cultural communication. Shape, line, and color represent any objects of the world and provide understanding meanings of the images. Connotations are characteristics not only of graphical forms, other objects of visual culture (VCU) (furniture, clothing, textiles, cars, etc.) could also be explained by a system of signs in social, historical and political contexts. Semantics and emotional feedback become very important in product design. Icons reflect the appearance of their labeled things, such as branded signs, where you can often find simplified or schematized images of animals, birds, fish or plants. Index marks (features signs, road signs, icons) are indicating designations of objects or situations that are concise and used to distinguish these objects and situations from a number of others: suitcase is the designation of luggage, a cup means cafe, the Eiffel Tower - index mark of Paris, Sagrada Família by Antoni Gaudí is Barcelona sign. Signssymbols (conventional signs, signals) are based on a symbolically established connection between the sign and represented object; visualize features of objects/concepts/ideas/facts/ phenomenons in a social-legal dimension. E.g., svarga is a symbol of life and movement, solar sign; the trident in ancient Ukrainian mythology also symbolized movement and belonged to Stribog-Zemlederzhets (one of Pagan Gods). Often red heart is a symbol of love in advertising. Johanna Drucker and Emily McVarish say:

"All signs and images as coding of certain meanings must form a state of reliability, stability, openness to the consumer and do not contain negative meanings or interpretations. Therefore, visual code is an established sign system in the graphic form" (2013, p. 366).

Visualization provides the basis for a comprehensive analysis of advertising informing means and their impact on society (symbols, ornaments, colours, trademarks and corporape identifications, Web graphics, video advertising, Internet banners, print and outdoor advertising). In addition, it is an inalienable source of the development of creative concepts in design. Besides, case studies provide a link between ideas and their practical implementation. VL becomes decisive, transmits ideas, actively affects consciousness, promotes the formation of visual competence, the ability to read and critically analyze visual signs, and expands cognitive potential of research methods. This allows advertising to maintain dynamics of socio-cultural life.

Gillian Rose proposed a critical visual methodology for defining and interpreting an image meaning: image itself, image creation and audience reaction to image that can be studied in three aspects: social, compositional, and technological. The conclusions of this work show its usefulness not only for photography but also for related disciplines such as communication, education, cultural and media research. This form of analysis also finds a place in the wider environment of social or cultural identity. In addition, Rose regards that in most semiotic analyses, the focus on image itself is considered to be the most important in order to understand how the structure of images forms cultural senses (2001, p. 106). Since semiotics focuses on the meaning of signs and their interpretations on semantic level, composite and social conditions also play an important role in the interpretation of meanings. 
The most important for visual semiotic analysis is an image reviewed as reflected in itself. Thus, the researcher believes that Barthes' analytical base of different levels of significance in postmodern environment with the use of notation, connotation and myth will affect this aspect of semiological understanding in the construction of self-identification through objects and images. In compositional modality, each advertising media might have common design elements that help to create an integral look for advertising functioning.

James Elkins is convinced that in the nearest future VR will merge and radically transform art studies as a scientific discipline. He is interested in the problems of vision and describing the visual world, the problems of system and non-system character. Based on the above said his research is of interdisciplinary character, covering the history of art, anthropology, sociology, the theory of cinema, theater, literature and media in order to realize visualization as increasing activity of perceiving entity. Consumer groups reveal VCU research in advertising appealed by producers of commercial images broadcasting the corresponding meanings (Elkins, 2010, pp. 348-353). Almira Usmanova distinguishes two paradigms: the first is based on the ability of visual image to construct social reality; the other interprets everyday life and appears as socio-cultural representation that reveals the ideology of the authors and involves some manipulations with viewers. She identifies three subject areas for visual appeals research (Usmanova, 2006, p. 11):

1) who created or implemented image and why?

2) image meaning and what channels was it presented through;

3) image perception by the audience and further interpretations.

Draws attention to the fact that semiotics also reveals symbolism of the ornament combined with methods of ethnography, folklore, archeology, religion and art studies. Every traditional culture provides an ornament, like a language, as an information system in which visual symbols correspond to emotional associations and verbal values, which are captured by folk names of patterns and motifs, their compositional, colour, and textual peculiarities. In our opinion, this uncovers new approaches to understanding the typology and stylistics of ornamentation - a determining factor in advertising. In the following parts we conciders the means of advertisings visualization.

\section{Visual language of advertising}

Compared to verbal language, the visual elements are perceived faster, easier, and more precisely. Any form of communication takes place by means of signs. Signs advertising information has three aspects, as well as Peirce's theory (1934): pragmatic (the influence of advertisings on the behavior consumers), semantic (link signs with advertised objects), syntactic (combination of signs). The design skills and creativity are not sufficient conditions for success. Equally important are the profound knowledge of consumer psychology, marketing, understanding of social-economic phenomenons and trends. In context of increasing market competition, it is necessary to find effective ways of creating images, based on the integration of art-proecting and marketing thinking.

Tomas Kačerauskas, presenting the concept of creative society, points out that originality, semantics, aesthetics and certain frames, in this case, in sociological context are very 
important. The structured approach helps to understand this. The creativity requires more and more knowledges and skills in contemporary society filled with technology and media. The creative society involves a creative way of life (productions of new ideas, free work schedule, the absence of strict fixation working time, inseparability of work from leisure, consumption culture also). The creativity components, and their socio-cultural evaluation are problematic and difficult to establish with using empirical methods, but the philosopher concludes that the emergence of creative class as a new social formation, and also creative thinking, intellectual capital, innovations, cultural clusters will contribute to regional and urban researches, and the development of creative industries (Kacherauskas, 2017).

Problems of ideas visualization are consist that in the conditions of contemporary oversaturation of information, in particular, advertising and stylistic chaos, the concretic is absent, how to make a non-standard appeal, not just attracting the attention of the consumers, but also capturing theirs consciousness to the advertising object.

Advertising discourse can include a verbal component (oral or written), visual (image or video), sound (musical or noisy accompaniment), tactile (flavor, for example). In addition, advertising placement can be symbolic. The focus moves from informative function to communicative. Aesthetic function is introduced in advertising through its sign functions; therefore, semiotics and aesthetics are inseparably linked in this case. In contrast with cultural studies, advertising discourse always contains explicit or implicit arguments, using suggestive methods of supplying commercial information. Currently, manipulative techniques in advertising are applied very aggressively. Social advertising does not meet similar resistance of consumers, as it contains ideas easy to understand and avoids commerce.

The VL of advertising has undergone significant changes - the contemporary forms of advertisings differ from the advertisings of the 18th-19th centuries by VMs, and by methods of psychological influence on the consumer. During its existence advertising influenced the buyer and convinced him, using his own tastes and ingenuity of advertisers. Often advertising was unexpected, sometimes - highly artistic forms. At the beginning of the 20th century scientific method based on associative psychology was formed, which resulted in significant effectiveness of advertising influence - there was a transition from informing to the sign of consumption objects (Dayan, 2003, pp. 17-18):
"Symbolic value of product for the client, which finds in it the fictional satisfaction of their own needs, is formed at the expense of values artificially combined into a holis- tic image. Semiotic analysis of Advertising helps to understand its language "aposteri- ori", and sometimes the authors themselves are surprised at how many hidden mean- ings and allusions can be found in the messages they created" (Dayan, 2003, p. 47).

Metaphor becomes the basic characteristic of contemporary VCU, the instrument for integrating abstract and concrete, the interpretation of complex ideas and the combination images with emotions, creation and emphasition new meanings, which is so important in advertising. The advertising line for brand Smirnoff in late 1990s can be vivid example of metaphorical images in print advertinsings and on television, which were immediately remembered for many years (the orchid through vodka bottle turned into predatory flower, the banker - into thick penguin, the sheep - into wolf under a sheepskin, the pretty woman into panther). 
Hyperbolization is the second technology behind the frequency of use in advertising. Exaggeration of positive characteristics the product or service increases expressiveness and emphasizes the originality advertisement.

Developing and fully supporting one or more positive associations, the manufacturer/ entrepreneur gets opportunity to create additional value of the product, to allocate an organization among its competitors, to individualize it, that in today's market conditions is a guarantee not only of survival but also of successful functioning. Often various intertextual links from direct quotations to subtle allusions (hints on certain historical, mythological, everyday facts, fixed in culture) are presented in advertisings.

Allegory is artistic method, imaging of abstract concept or phenomenon through a particular image, creative advertising technology that avoids banality, cliché in presented the advertising objects.

Metonymy is more complicated than metaphor. This is the transition of a form into the form, renaming, defining one object through another in close connection, matching, irrational of its character.

It is necessary to consider not only the content aspects in AGs but also the formal, which should correspond to the accessories of viewer to a particular social group, for example, a person without education, which have simple physical labor will be clearer advertising poster using the photo of the proposed item than complex formal composition from geometric elements, and even more so associative. This implies an important position: the social aspect of aesthetic perception determines the art-expressive means of advertising. AGs, based on the achievements of "elitist" art, uses elements of its expressive language - by introducing simplified and modified elements into ordinary mass consciousness, advertising promotes and brings it closer to mass art. However, such messages are often quite complex, incomprehensible to most consumers, contrary to the logic of advertising information. After all, an advertising message in its essence - it is a lucid and attractive reflection of the characteristics product or services, and advertising should still sell the product, and not be just a "masterpiece of art". In general, advertising can not be elitist, it is aimed at mass perception, average consciousness, standardized collective behavior and should be accessible to all social groups.

The main problem of contemporary advertisings is the contradiction between commercial and aesthetic factors. Advertising philosophy is aimed at making profits, which is the most important component of the advertising process, but cultural, ideological and moral-psychological components are no less important. It is based on the "platform" of rendering advertising idea. For advertising effectiveness, there are two components: content must fully meet the stated purpose of advertisements and be oriented towards the selected market segment. The essence of economic efficiency advertising is fast and understandable, and the communicative, psychological efficiency is more prolonged in time and consists in the formation positive image of the advertised object. Advertising designers, on the one hand, are dependent on the market situation, and on the other - from the ability to sensually experience and create an artistic (advertising) images. 
At the intersection of sciences there was new discipline - "neuromarketing" as a manipulative means of consumer consciousness. The German researcher Arndt Trindl, the founder of neuromarketing, based on recent brain studies, in his work "Neuromarketing: The Visualization of Emotions" argues that human behavior is driven mainly by emotion rather than reason, so visual perception becomes crucial in choosing and acquiring the product (2009). All sensory signals first acquire an emotional assessment (emotionally significant or not), and only then pass to the level of consciousness (logical analysis). Perception, as a rule, is subordinated to the motivational system, which is formed genetically and socio-cultural. $\mathrm{He}$ also recommends creating a positive emotional background in advertising with colours, focusing on the significant influence of cultural and social associations in the perception of colour combinations.

In connection with the monotony and variety of images, the enormous advertising overload on all media channels, the so-called "advertising noise", which reached the critical limit, active searches for original advertising ideas continue, advertisers already at the level of informative advertising prefer creative approaches - non-standard forms, visual semantics, double meaning, use of the object advertising in unusual situations. Therefore, the concept of "creative" is quite complicated in the design-practice. The designer can not be creative, not creative, then it is just a performer, a craftsman, a student (an apprentice, as they used to say earlier), a layman. However, creativity, which is understood only by the developer of advertisings, frank vulgarity or epatage, is not an end in advertising. Such "creativers" forget the elementary truth that the main advertising purpose is to sell the consumer products or services. For this, interesting, attractive images, emotional, humor, and satire are needed nowadays, that's why, the use of creative technologies becomes more important when creating an advertisement as a visual-verbal model.

"Zag" in the lexicon of Marty Neumeier, well known Californian graphic designer and brand-communications specialist, is a radically differentiated market position ("when everyone zigs, zag"). Due to knowledge of how the mechanism of human perception and the corresponding decision-making works, one can solve the main task of neuromarketing - to achieve from the person the necessary consumer behavior: "Designing - bringing together strategic and creative processes to achieve a shared goal” (Liquid Agency, 2019).

Our generalization and classification of empirical advertising materials from 18th century allows coming to conclusion that AGs, and, after it, AD borrows style features of graphic art and crafts world art. Advertising evolved from illustrative accompanying of commercial information to appearance of new styles (or pseudo-styles) in frames of mass culture from second part of 20th-the beginning of 21 st century. In this context a lot of mistakes in AGs were exposed: prevalence of stereotypes, primitivism, vulgarity and the absence of national imagery; pop art, kitsch, eclecticism dominanting in advertisings. In spite of main task of advertising - attracting attention of potential clients to one of many products, as a rule, similar products and create its positive image for long term memorizing, means of visualization mostly have low aesthetic level. Based on comparative analysis the advertising images of different times, we have identified the chronological stages in the choice of VMs (Table 1). 
Table 1. Advertisings visualisation in chronological stages (source: created by author.)

\begin{tabular}{|c|c|}
\hline \multicolumn{2}{|c|}{ I phase, the most prolonged (18th-19th centuries) } \\
\hline $\begin{array}{l}\text { During the 17th-19th centuries the development } \\
\text { of trade relations and industry were required } \\
\text { advertisements. Regional cultures, ethno-artistic } \\
\text { traditions, folk arts crafts have been displayed } \\
\text { in posters, signboards, packages, newspapers, } \\
\text { thematic exhibitions. }\end{array}$ & $\begin{array}{l}\text { Purely figurative stage, advertising then did not } \\
\text { differ much from the works of fine art. Realism, } \\
\text { classicism, ethno-stylistics. At the end of 19th } \\
\text { century modern/Art Nouveau/secession/liberty/ } \\
\text { Jugendstil/Tiffani had the leading positions. }\end{array}$ \\
\hline \multicolumn{2}{|c|}{ II phase (beginning of the 20th-the I half of the 20th century) } \\
\hline $\begin{array}{l}\text { New ideological and aesthetic concepts. The } \\
\text { categorical denial of academic approaches } \\
\text { in art, the active search for new means of } \\
\text { expressiveness. Poster is the main means of } \\
\text { propaganda, branching into commercial, } \\
\text { political and public. Printed and outdoor } \\
\text { advertising were dominated. }\end{array}$ & $\begin{array}{l}\text { Formal stage was based on means of avant- } \\
\text { garde: abstractionism, cubism, fauvism, } \\
\text { expressionism, futurism, dadaism, surrealism, } \\
\text { functionalism, pop art, op art, minimalism, } \\
\text { international typographic style. Visualization in } \\
\text { advertisings used the mainly constructivism and } \\
\text { suprematism. }\end{array}$ \\
\hline \multicolumn{2}{|c|}{ III phase (II half-the end of 20th century) } \\
\hline $\begin{array}{l}\text { Confrontation of various ideological systems. } \\
\text { Globalization, mass culture, commercialization } \\
\text { of art, multiculturalism, cultural assimilation, } \\
\text { subculture, counter-culture. Absurd and fantasy, } \\
\text { irony and humor as artistic methods. Epitaph, } \\
\text { remake, improvisation, performance. Emergence } \\
\text { of video advertising, synthesis of genres in } \\
\text { media culture, active interaction of visual and } \\
\text { verbal aspects. }\end{array}$ & $\begin{array}{l}\text { Synthetic stage, which combined various imaging } \\
\text { means of antecedent stages, Postmodernism } \\
\text { captures all spheres in creativity. Eclecticism, } \\
\text { fragmentation and strategic instability, neo- } \\
\text { and pseudo-stylistics. The visual metaphor } \\
\text { becomes universal stylistic figure, the complexity } \\
\text { of image, its deconstruction. Hyperrealism, } \\
\text { photography and computer graphic programs to } \\
\text { display a products or consumers. }\end{array}$ \\
\hline \multicolumn{2}{|c|}{ IV phase (early 21st century) } \\
\hline $\begin{array}{l}\text { Postglobalization (de-globalization), } \\
\text { transculturalism, the searches for national } \\
\text { identity and revival of regional cultures, } \\
\text { monoculture in some countries, cultural } \\
\text { exchange is complicated by tense geopolitical } \\
\text { situation. Digital era, the emergence of Internet } \\
\text { advertising, ambient advertising (on non- } \\
\text { standard carriers), peak of installations and } \\
\text { performance. Transition from "conceptual" } \\
\text { perception to the level of emotional images } \\
\text { (clipped perception and thinking). Discursive } \\
\text { practices in various spheres of culture, art, } \\
\text { design, advertising and media. }\end{array}$ & $\begin{array}{l}\text { Imagery-associative stage, in which the artistic } \\
\text { image, aesthetic eclecticism, emotionality and } \\
\text { originality are put forward. Post-postmodern } \\
\text { appears as definite image through creative } \\
\text { advertising technologies: metaphor, hyperbole, } \\
\text { association (or allusion), metonymy and allegory. } \\
\text { Conceptual search for new styles, returning } \\
\text { functionalism and minimalism, leading } \\
\text { polystylism. Visual semantics, colour becomes } \\
\text { a significant visual channel for communication, } \\
\text { flat colours and shapes, decor is absent. 3D } \\
\text { images, big possibilities of computer effects. }\end{array}$ \\
\hline
\end{tabular}

\section{The national and international features of advertising: glocalization or globalization?}

In second decade of the 21 st century the process of de-globalization began, more and more advertisers are beginning to develop glocal markets, countries restrict co-trade, and a nationally-oriented approach is intensifying. This is due not so much to military conflicts and political factors, but with new production technologies and individual approach to the consumers. The direction of industry to regions substantially changes the world market structure. 
Orientation of production to regional groups, significant change of market policy presupposed cardinal change in tasks and character of advertising: socio-psychological, cultural and aesthetical indices become very actual. Definition of imagery as specific means of creating image from the point of view of definite aesthetic ideal is a key to understanding the process of projecting image in $\mathrm{AD}$. Ethno-design is becoming increasingly popular, which brings to the urbanized standardized life a sense of artistic expression. Most often there are furniture, accessories, stylized decor elements of East, Africa, Egypt and Greece. It remains relevant and justified to use the ethno-art tradition to identify countries, goods and services in the world, preservation of national cultures. If in the printing and packaging of the early 20th century numerous designs in the "folk style" were built on the active use of ornamental motifs, today the innovative design ideas must be combined with the traditional features of Slavic mentality (emotional perception of the environment, love of native nature, lyricism, admiration of language, folklore and bright rituals, the desire for internal and external harmony, careful attitude to life and folk art, ability to self-irony).

Video and banner advertising in virtual space we are considers as visual ideologies in the NM. In spite of its main commercial function, advertising was recognized as cultural phenomenon due to visual aids of AC that become logical reflection of socio-cultural state of society in definite periods. Unfortunately, in most cases modern means of ad information do not contribute to forming outlook, art thinking development, aesthetic perception of reality, etc. On the base of the analysis of contemporary adverts we can clearly separate two main tendencies of visualization: first - ideological orientation of middle class consumers to "life in luxury style", second - orientation towards mass consumer, catching attention, exclusive brightness and diversity of colours in advertisements. Consumerism became an ideology of post-modernism, media popularize hedonistic way of life and consuming type of personality. Post-modernism has its own typological features: the use of any ready forms from art to utility, widespread of photography and computer special effects, deliberate violation of commensurable quantities of visual elements, borrowing the ideas from other types of art, remake, interpretation, combination, fragmentation, epatage, installation, collageness and replicability of the projects.

Now the frames of post-modernism are widening; forming of new stylistic trends in architecture, art, design and advertising is made by deliberate synthetic approach in the use of variable elements, wide spread of irony and giving new context to old forms, complexity of the sense of harmony, increasing the variety of genres, reinterpretation of artistic traditions, accepting the coexistence of different cultures and dialogue of cultures. Post-modernism is characterized by "game" with the cultural layers of nations. To the certain extent, it is an environment for the development of national form in design, media and advertising, where one of the leading ones is becoming ethno-style (neofolk). Among the reasons for its revival can be called the need for identification of goods and services in the world, and awareness of the person himself as an heir and guardian of national traditions. We think that the cultural heritage of many countries is the basis for the further development of ethno-design. Recall only the stylistics of Scandinavia, Provence, Tyrol, Japan, Ukrainian, and Mexico. Christmas fairs in Europe, in particular Munich, Prague, Warsaw, Lublin and Wroclaw, demonstrate steady interest in promouting-souvenir products from the regions of Ukraine. At the same time, pseudo-Ukrainian souvenirs of Chinese manufacture dominating over recent years at fairs, festivals and stores in Western Ukraine and Poland. Authentic Ukrainian products are 
actively supplanted by Chinese counterfeiting: ceramic and wooden products, embroidered clothes, icons, and losted among Chinese "trash".

The situation is different in Internet, where the functionality of international style prevails. We are analyses Web advertising as actual mass media which using combination the saturated colour-graphic forms, sound, animation and digital visual effects. Digital formats in the outdoor advertising of Europe and the US (city-lights and city-boards) are already becoming standard and have several benefits: greater attraction, more demos of various advertisements, more frequent changes in video advertisings. That with advanced Web technologies and economic efficiency factors will be one of the most promising means of the ACs in future. Mostly, will be appreciate specialists with hybrid skills, those who understand technologies and have both the creative and analytical thinking.

So, the results and theoretical significance of the research carried out is manifested in the conceptual and predictive levels, which influences the development of AD in general. However, it is necessary to distinguish the concept of "AD" and "design of advertising", which are not identical. AD should be understood as a type of contemporary design activity that synthesizes many related areas, and design of advertising - as educational discipline aimed at mastering the methodology of designing advertising products. We have proposed the orientation of professional training for design-marketing and advertising for graphic designers of the Master level, which is reflected in the author's educational complex and textbook Design of Advertising and the State standard for specialty 022 "Design", approved by the Ministry of Education and Science of Ukraine in 2018, as well as the certificate program "Visual Language of Advertising Communications" in the framework of advanced training in National Academy of Managerial staff of Culture and Arts (Kyiv).

In summary, researching the AGs as product of culture in the wide context, special attention is paid to the art-aesthetic problems of $\mathrm{AD}$ objects. The range of topics and variety in the design process need for critical analysis of visual data, and synthesis of disciplines that cover the many manifestations of this new integrative tendency. It is proved that advertising discourse is a type of communicative activity, takes place in the cultural world area and actively forms the visual semantic structures. The functionality and aesthetics the forming means in the process of visualization advertising ideas from affiche (poster) to DM are emphasized.

\section{Recommendations of the study}

In the article an interdisciplinary discourse on creative technologies in the context of AD was conducted, which allowed to formulate practical recommendations and determine the essence of the tasks of advertising in accordance with the object of the study:

1) AGs must be understood as an integral part of the advertising design, and advertistment - as a clear communicative structure that has socio-cultural content, visual semantics, emotionality, conciseness, contrast and dynamic colour balance, originality, image clarity, art-aesthetic level and stimulates the intellectual activity of consumers;

2) It is necessary to take into account the cultural and historical development of advertising in practical activities and the proposed periodization of visual means with appropriate stylistics based on artistic styles and ethno-art traditions of different countries; 
3) It is also worth structuring the compositional, semiotic and aesthetic aspects of colourgraphic materials in advertisings, preserving the values of archetypes and cultural symbols, using techniques of creative interpretation and artistic imagery, social or cultural types, as well as creative advertising technologies (metaphor, hyperbole, association, metonymy, allegory).

\section{Conclusions}

There are no ready-made promotional ideas, each of them depends on the particular product and its positioning on the market, as well as the complex of socio-cultural, regional and economic factors. Developing the original and effective advertising idea is difficult enough even for professionals, since an advertising message should be the end result of whole series of studies. The use of VMs in advertising should be determined by targeting, taking into account certain aesthetic ideals, national colouristics and ethno-art traditions. AGs considered as art component of designing advertisements, and advertising creativity was analized in the context of socio-cultural communications. The advertising products for consumer groups must have aesthetic level and implement cultural-education function.

Designers, who working in the media, based on perception of painting, drawing, photography and installation, should develop strategies for visualizing different concepts. Creates a virtual world, designed for "digital activity": trade, games, entertainment, education, communication, virtual travel. Sites and social networks become like shops or exhibition pavilions. In the Internet space aesthetics of the composition is aimed at communication of values, and the constructive structure is changed to the visual expression of computer graphics. The debate is not about technological issues, but about the emergence of new type of culture. Saturated images of television, video-, computer games, animations create socio-cultural conditions for the expansion of new art practices. Our proposed conceptual provisions for the $\mathrm{AD}$ development in Eastern Europe taking into account the experience of America and Western Europe consist in expanding and deepening the methodology of project thinking, introducing the theoretical and methodological bases of culture and media studies into practice and design-education, and concretizing the specialized terminology.

\section{References}

Afanasiev, Yu. (1990). Sociokul'turnyj potencial hudozhestvennoj dejatel'nosti. Lviv: Svit.

Barnard, M. (2001). Approaches to understanding visual culture. New York, NY: Palgrave. https://doi.org/10.1007/978-1-137-11046-6

Barthes, R. (2003). Modnaja sistema. Stat'i po semiotike kul'tury. Moskva: Izdatel'stvo Sabashnikov.

Bovman, V. (1971). Graficheskoe predstavlenie informacii. Moskva: Mir.

Castells, M. (2009). Communication power. Oxford: Oxford University Press.

Danylenko, V. (2005). Dizajn Ukraïni u svitovomu konteksti kul'uri mistec'kogo proektu. Kharkiv: KDADM, Coloryt.

Dayan, A. (2003). Reklama. Sankt-Peterburg: Neva.

Design Council. (2019). Design council. Retrieved from https://www.designcouncil.org.uk/ 
Drucker, J., \& McVarish, E. (2013). Graphic design history: a critical guide. New York: Pearson.

dschool.stanford.edu. (2019). Welcome. Retrieved from https://dschool.stanford.edu/

Ehmer, H. K. (Hrsg.). (1980). Visuelle Kommunikation: Beiträge zur Kritik der Bewusstseinsindustrie. Köln: M. DuMont Schauberg.

Elkins, J. (2010). Izuchenie vizual'nogo mira. Vilnius: Evropejskij gumanitarnyj universitet.

Fed, V. (2009). Kul'tura-tvorchist' Buttja. Slov'jans'k: Drukovanij dim.

Frascara, J. (2004). Communication design: principles, methods, and practice. New York: Allworth Press.

Gerchanivska, P. (2017). Analiz kul'turi v paradigmi teorii sistem. Visnik Nacional'noi akademii upravlinnja kulturi i mistectv. T. 1. Kyiv: Millenium.

Giddens, A. (1999). Sociologija. Moskva: Redakcija URSS.

Griese, N. L. (2001). Arthur W. page: publisher, public relations pioneer, patriot. Tucker, GA: Anvil Publishers, Inc.

Harvard University Graduate School of Design. (2019). Harvard University Graduate School of Design. Retrieved from https://www.gsd.harvard.edu/

Eko, U. (2019). Innovacija i povtorenie. Mezhdu jestetikoj moderna i postmoderna. Retrieved from https://www.gumer.info/bibliotek_Buks/Culture/Eko/Inn_Povt.php

Jevler, J. (2003). Kreativnye strategii v reklame. Sankt-Peterburg: Piter.

Kacherauskas, T. (2017). Kreativnost' i koncepcija kreativnogo obshhestva v sociologii. Vestnik Rossijskoj Akademii Nauk, 10, 26-35.

Kaftandjiev, H. (2012). Absolut semiotics. Sofia: Siela.

Kokemuller, N. (2019). Creative advertising concepts. Chron. Retrieved from https://smallbusiness. chron.com/creative-advertising-concepts-18561.html

Kostina, A. (2011). Massovaja kul'tura kak fenomen postindustrial'nogo obshhestva. Moskva: LKI Publishing.

Liquid Agency. (2019). ZAGWEEK: A great branding experience. Retrieved from https://www.liquidagency.com/brand-exchange/zagweek-a-great-branding-experience/

Lotman, Yu. (2001). Semiosfera. Sankt-Peterburg: Iskusstvo.

Malamed, C. (2009). Visual language for designers: principles for creating graphics that people understand. Beverly, MA: Rockport Publishers.

Manovich, L. (2002). The language of new media. Series: Leonardo. R. F. Malina (Series Ed.). Cambridge, Massachusetts: MIT Press.

Margolis, E., \& Pauwels, L. (Eds.). (2011). The SAGE handbook of visual research methods. Los Angeles: SAGE Publications. https://doi.org/10.4135/9781446268278

Noble, I., \& Bestley, R. (2011). Visual research: an introduction to research methodologies in graphic design. Lausanne: AVA Publishing SA.

O'Connell, R. M. (2015). Visualizing culture: analyzing the cultural aesthetics of the web. Series: Visual Communication. S. B. Barnes (General Ed.). Vol. 4. New York: Peter Lang Publishing, Inc. https://doi.org/10.3726/978-1-4539-1290-4

Papanek, V. (2004). Dizajn dlja real'nogo mira. Moskva: Izdatel'stvo Aronov.

Peirce, Ch. S. (1934). The collected papers of Charles Sanders Peirce. Vol. V: Pragmatism and Pragmaticism. Cambridge: Harvard University Press.

Pryshchenko, S. (2018). Hkudozhno-obrazna systema reklamnoyi grafiky. Kyiv: Nacional'na akademija upravlinnja kul'turi i mistectv.

Research Park, University of Illinois Urbana Champaign. (2019). Research Park, University of Illinois Urbana Champaign. Retrieved from http://www.researchpark.illinois.edu/

Rose, G. (2001). Visual methodologies: an introduction to the interpretation of visual materials. London: SAGE Publications. 
Rozik, E. (1997). Pictorial metaphor in commercial advertising. In W. Nöth (Ed.), Semiotics of the media: state of the art, projects, and perspectives (approaches to semiotics) (pp. 159-174). Berlin, New York: Mouton de Gruyter. https://doi.org/10.1515/9783110803617-012

Sapeńko, R. (2005). Iskusstvo reklamy v sovremennoj kul'ture. Kyiv: Kljaksa Poligrafija.

Shtompka, P. (2007). Vizual'naja sociologija. Moskva: Logos.

Sivers, V. (2014). Cinnist' jak gorizont kul'turnih podij. Kul'turologija. Filologija. Muzikoznavstvo. T. 2. Kyiv: Nacional'na akademija upravlinnja kul'turi i mistectv.

Stanczak, G. C. (2007). Introduction: images, methodologies, and generating social knowledge. In G. C. Stanczak (Ed.). (2007). Visual research methods: image, society, and representation (pp. 1-22). Los Angeles: SAGE Publications, Inc. https://doi.org/10.4135/9781412986502

Swiss Design Network. (2019). Swiss design network. Retrieved from http://swissdesignnetwork.ch/

Sydorenko, V. (1990). Genezis proektnoj kul'tury i jestetiki dizajnerskogo tvorchestva. Rasshirennaja annotacija doktorskoj dissertacii po iskusstvovedeniju. Moskva: Vsesoyuznij nauchno-issledovatel'skyj instytut tehnycheskoj estetyky (unpublished source).

Trindl, A. (2009). Nejromarketing: vizualizacija jemocij. Moskva: Al'pina Izdatel'.

Usmanova, A. (2006). Vizual'noe issledovanie kak paradigma. Vizual'nye aspekty kul'tury. Vilnius: Evropejskij gumanitarnyj universitet.

Wernick, A. (1991). Promotional culture: advertising, ideology and symbolic express. London: SAGE Publications Ltd. https://doi.org/10.1007/978-1-349-22346-6_17

\title{
KŪRYBINĖS TECHNOLOGIJOS REKLAMOS DIZAINE
}

\section{Svitlana VALERIIVNA PRYSHCHENKO}

\begin{abstract}
Santrauka
Šio straipsnio tikslas - išanalizuoti esamas metodologines meno, kultūros, dizaino, reklamos prieigas, siekiant sukurti efektyvų reklamos produktų dizainą, didinant teigiamą orientacinę jo vertę ir keliant estetinį lygị. Tyrimo sritis - reklamos idejjų vizualizavimas, atsižvelgiant ị regiono specifiką ir etnokultūrinį tapatinimąsi. Kultūrinio-estetinio reklamos dizaino komponento mokslinio tyrimo tikslas - susisteminti vizualines informacijos priemones ir suformuluoti kompleksinę jų funkcinių charakteristikų apibrèžtị, kuri šiuolaikinëje visuomenejje yra gerokai platesnè nei prieš trisdešimt metų. Reklamos grafika pristatoma kaip vizualusis menas, vizualinė kultūra ir vizualinė komunikacija. Pavyzdžiui, naudodamiesi spalvinėmis grafinemis vaizdinėmis priemonėmis, aptarème kūrybines reklamos technologijas: metaforas, hiperbolę, asociacijas, alegorijas ir metonimijas. Produktų orientavimas ị regioninių vartotojų grupes, reikšmingas rinkos politikos pokytis paskatino radikalų reklamos uždavinių ir pobūdžio pasikeitimą: tapo aktualūs sociopsichologiniai, kultūriniai ir meniniai-estetiniai rodikliai. Vaizduotès kaip ypatingos kūrybiškumo priemonès apibrěžtis skirtingų estetinių idealų požiūriu - tai pagrindas, leidžiantis suprasti meno projektavimo procesą. Šiame išsamiame tyrime apibendrinama reklamos grafikos stilistika tarpkultūrinès komunikacijos kontekste, pradedant plakatais ir baigiant naujomis reklamos formomis - skaitmeninemis medijomis.
\end{abstract}

Reikšminiai žodžiai: reklamos dizainas, reklamos grafika, meninè vaizduote, plakatas, skaitmeninès medijos, vizualinè estetika. 